\title{
Understanding the health needs of adult men: a male perspective
}

\author{
Compreensão sobre as necessidades de saúde de homens adultos: perspectiva masculina
}

Guilherme Oliveira de Arruda ${ }^{1}$, Áurea Christina de Paula Corrêa², Sonia Silva Marcon ${ }^{1}$

Objective: to understand the health needs of adult men from a male perspective. Methods: it is a qualitative research, performed with ten men, aged 29 to 59 years old. The data were collected in semi-structured interviews and submitted to the content analysis, thematic modality, using the Health Needs Taxonomy. Results: men's health needs are related to living conditions as financial, emotional and political aspects, and attendance in health, based on the respect and access to technologies, including the need to bond with professionals of reference and autonomy in the way of taking care of themselves. It is observed that these needs are influenced by social constructions of gender. Conclusion: male health needs are diverse, heterogeneous and socially constructed, and I requires inter-sectional actions in understanding the breadth of these actions to establish effective care.

Descriptors: Men's Health; Health Services Needs and Demand; Gender and Health; Nursing.

Objetivo: compreender as necessidades de saúde de homens adultos, sob a perspectiva masculina. Métodos: pesquisa qualitativa, realizada com dez homens, com idades de 29 a 59 anos. Dados coletados em entrevistas semiestruturadas e submetidos à análise de conteúdo, modalidade temática, utilizando-sea Taxonomia das Necessidades de Saúde. Resultados: as necessidades de saúde dos homens perpassam pelas condições de vida, abrangendo aspectos financeiros, emocionais e políticos, e por atendimentos em saúde, pautados no respeito e acesso às tecnologias, incluindo as necessidades de vínculo com profissionais de referência e autonomia no modo de cuidar-se. Observa-se que estas necessidades são influenciadas por construções sociais de gênero. Conclusão: as necessidades de saúde masculinas são diversas, heterogêneas e socialmente construídas, e requerem ações intersetoriais na compreensão da amplitude destas para o estabelecimento de um cuidado efetivo.

Descritores: Saúde do Homem; Necessidades e Demandas de Serviços de Saúde; Gênero e Saúde; Enfermagem.

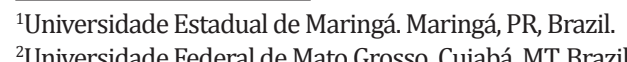

Corresponding author: Guilherme Oliveira de Arruda

Rua Doutor Saulo Porto Virmond, 768, Chácara Paulista, CEP: 87005-090. Maringá, PR, Brazil. E-mail: enfgoa@gmail.com 


\section{Introduction}

The health needs are a central component of the healthcare production because they involve elements perceived as indispensable by the individual to reach and maintain good conditions of life and health, according to their values and desires. In the flow of events that need for care, the influence of social determinants and the perception of problems result in the search for care $^{(1)}$. Therefore, it is necessary to recognize that the health needs perceived by the individuals/users may differ from those recognized by the professionals since as a rule, they tend to focus on biological demands.

However, needs are not exclusively medical problems or illness, suffering, and risk. They are also expressed what is perceived as necessary to be healthy and enjoy a good life, which distinguishing between individuals and collectivities ${ }^{(2)}$. By taking such a theoretical perspective as reference, it is evident that it is necessary to know the health needs of the individuals involved in the care production/consumption process, above all, from subjective, social and historically constructed conceptions that bring meanings related to the way of life and that can subsidize the work process in health ${ }^{(3)}$.

Regarding to the identification of health needs, specifically of adult men, studies are still scarce. Internationally, studies have focused on topics such as prostate cancer ${ }^{(4)}$ and male sexual function ${ }^{(5)}$. In Brazil, the objects of this research are in line with the priorities defined by the National Policy for Integral Care to Human Health, such as the access to health services, sexuality, reproductive health, violence and major health problems for men ${ }^{(6)}$.

A study carried out with primary health care professionals in Ceará, Brazil shows that they are not aware and at the same time they are experiencing difficulties in implementing strategies capable of including men in health promotion and prevention activities, specifically for this group population as collective activities, with exclusive participation of male patients on specific themes of human health; and to link them to health teams. There is little recognition of the gender aspects that are involved in men's relationship with health and services, which hinders to approach this population ${ }^{(7)}$.

Despite the appreciation of health researchers and research institutions, there are still many difficulties in identifying and dealing with male health needs because the social and cultural constructions of gender and those related to masculinities influence behavior that distances the men of health $\operatorname{care}^{(7)}$. The recognition and socialization of men's health needs still face barriers imposed by the current model of masculinity, where there is no room for attention and care for the men demands and needs in health, but it favors the invulnerability of men. The reproduction of adverse postures to health care prevents reception and bonding ${ }^{(8)}$.

Thus, the relationship between men and primary health care services is superficial, since the link with the teams is still fragile. The limited supply of activities geared specifically to young adult males contributes to little demand for health services. Also, the shame to expose impatience, poor availability of time and lack of resolve by the health services are pointed out by men as obstacles to meeting health needs, limiting their identification and management ${ }^{(9)}$.

Therefore, the study of health needs with broader perception based on the conceptions of adult men can subsidize the professional performance for the care to be provided beside to the disease, emphasizing approaches restricted to prostate care or issues which, while representing significant demands, do not express the health needs of the men. The question is: what is necessary to be healthy, from the point of view of adult men? Thus, the objective of the study was to understand the health needs of adult men from a male perspective.

\section{Methods}

This is a qualitative study, with the participation of 10 men, aged 20 to 59 years old, selected for 
convenience. The inclusion criteria adopted were to have participated in a household survey (quantitative), to have been able to verbalize the answers, to be communicative and to make additional comments on the answers to the structured instrument, besides to agreeing to participate in a new interview to clarify the subject under study. The intention was to increase the possibility of those participants who showed greater interest in the subject, to express more about how they think and act on the 'health needs of the man', as well as to explore elements that arose in the structured interviews and did not could be addressed in the household survey, seeking to understand the research problem more broadly. There were 16 men contacted, of whom one was not found, one had moved to another city and four refused to participate.

The data were collected between January and February of 2014 through a semi-structured interview with an instrument elaborated by the researchers, containing the following guiding questions: what do you need to be healthy? What other conditions are necessary to live healthily in your case? The interviews were scheduled at dates and times according to the availability of the participants, performed in their homes to minimize interference in the answers on the health services environment.

The interviews lasted an average of 22 minutes, recorded through a digital recorder and recorded in full, generating 37 pages of written material. The statements were submitted to editing for elimination of language addictions. The analytical course was through Content Analysis, thematic modality to understand the health needs and the organization of the material accessed $^{(10)}$. The treatment of the data was given in the light of the Taxonomy of Health Needs ${ }^{(11)}$. The categorization of the data was carried out in the Molded Analysis Style, in which it is possible to define the categories of analysis a priori ${ }^{(12)}$. The Content Analysis reference allowed us to identify the most frequently expressed themes and the Health Needs Taxonomy enabled to fit these themes among the dimensions of health needs based on a relevant reference.

Based on the taxonomy of health needs ${ }^{(11)}$, there four categories of analysis adopted. The first category of necessities of good living conditions includes elements such as food, housing, transportation, and leisure, which represent basic health conditions. The second category, regarding the guarantee of access to all technologies, involves resources of the health services necessary to improve the health status of the people. In the third category, the need to link with a professional or health team, the relationship between users and health professionals is explored in the search for a reference of care. In the fourth category of the need for autonomy and self-care, the responsibility of individuals about their health and the way they conduct it, with the support of health professionals is addressed $^{(11)}$.

The excerpts from the testimonies are identified by the letter "M" ("Man"), followed by a representative number of the interview order and another by the age of the deponent. The study met the formal requirements contained in the national and international regulatory standards for research involving human beings, through Resolution 466/2012 of the National Health Council, approved under protocol no $162.077 / 2012$.

\section{Results}

The participants in this study were men, with a mean age of 47 years old, mostly married or in stable union. Two of them had no income, while the others were self-employed, employed or retired. Four men reported health problems (diabetes, neurological sequel, hypertension and gastritis associated with dyslipidemia). Four categories emerged: The need for good living conditions, Guarantee of access to different technologies, Need to create a link with the professional/health team and Need for autonomy and self-care in choosing the way to lead a life. 


\section{The need for good living conditions}

Men have suggested that the economic situation determines access to goods and services to maintain good health, as well as interfere with the emotional state. They also cited public policies for promoting these conditions. The need for work was one of the valued aspects in terms of health needs. Generally, when the person is poorer, she has more difficulty to acquire some things that she needs, then the degree of the conditions of buying a food, dressing a clothes, going to a very good doctor, she will have more difficulty (H.2, 58 years old). A more serious policy in relation to everything (H.3, 35 years old). I'm on leave. Work is very important. I quit working two and a half years ago and it seems I've aged five years (laughs) (H.6, 52 years old). Besides the person, obviously having an emotional balance, without a doubt, is being financially balanced (H.8, 44 years old).

Other elements, such as spirituality and religiosity emerged from the speeches as aspects related to good living conditions, as well as good family life. One thing that also influences, but people do not always perceive, is religiosity (H.2, 58 years old). First, Ineed to have peace of mind, I consider God very important (H.7, 46 years old).

When mentioning the need for good relationships, it was observed that social activities are relevant in adult life. It is noteworthy that religiousness and spirituality were referenced by men in different health conditions. The religiosity was highlighted by H.2 who suffered an automobile accident and had neurological sequels, and spent a long time in hospital and living with doubts about the prognosis. H.7, an individual who does not declare himself as ill, mentioned spirituality as a way to prevent illness.

\section{Ensuring access to different technologies}

It was verified that the men reported the need for access to the technologies of different natures, but, in general, they emphasized those needs related to the direct assistance to the health. Some interviewees mentioned the need for access to vaccines and tests; and others mentioned good care, consultations and governmental programs that contemplate the assistance demands of the male population, as the case with the female population. Having the vaccines in the right time, you make an appointment with the doctor and he will meet it (M.2, 58 years old). Where I go there to do my Prostate-Specific Antigens exam is very good, every time I needed the health center, it was always very favorable care (M.4, 57 years old). I think a good service is very important, a service of respect, I think it is lacking (M.5, 29 years old). Through the government line, they worry and show more the campaign of breast and cervical cancer, and for the man, they do not speak. The only thing they talk about is prostate cancer, but I think there should be some other programs to avoid hypertension, for example (M.5, 29 years old).

Although in the men's speech there was an agreement on the need for some technologies, there were also opinions about barriers to access to the exams, consultations with specialists and surgeries in the health services, which may motivate the man to launch self-medication, for example. Also, it was also observed in the speech of M.6, a reduction of the health demand to the needs resulting from the disease, which is in line with the restriction of the reference to the technologies of preventive and promotional health care. When these problems occur, we go to hospitals. A large number of Brazilians make this mistake that is self-medicating, so we usually take a painkiller (M.3, 35 years old). I think that the release part of exams hinders the problem, I think the release should be made direct where you made the request and was consulted. The specialist's search is also complicated (M.5, 29 years). Here, until it was good, but when we schedule, it takes a lot. If it is an emergency surgery, it takes seven or eight months, if you have to die two months earlier, you die. Nobody goes to the doctor without being sick (M.6, 52 years old).

Besides to guaranteeing the access to technologies, men also highlighted elements related to the need for linkage, as follows in the next category.

\section{Need to create a link with the professional/health team}

The need to have a professional of reference was evident in the speeches of the participants of this study, especially in doctors and dentists, since they consider that the topics between the patient and the professionals are always the same, since the professional keeps track of the history of the process health-illness of this patient and his/her family. Also, the relationship between the search for the reference professional and better results regarding health main- 
tenance was also noticed. It is a doctor and a dentist with whom I'm doing dental work, always the same. It is good because we arrive and they already know what it is, they already talk (M.6, 52 years old). They always have some doctors you feel more comfortable talking and trusting. If it is a professional giving this confidence, I will have a much better result (M.8, 44 years old).

There are those men who mentioned fragilities in the creation of a link with the professional, especially with the doctor, provoking the occurrence of mechanized and medicalized attendances that, seem not to unfold in other meetings. You go, talk what you are feeling, you receive a medicine, then I believe that the service is very mechanized (M.3, 35 years old). The doctor does not even look at you and says, "you have a virus" and send you away, he gives you a medicine and do not collect blood to know what it is (M.5, 29 years old).

Thus, the men interviewed expressed a sense of criticism regarding the quality of care, the therapeutic resources and the skills of health professionals.

\section{Need for autonomy and self-care in choosing how to lead a life}

The men recognized the importance of certain behaviors for health maintenance, indicating a condition of greater autonomy and even self-efficacy on the self-care based on concrete goals and corresponding to their own needs. I think that to live well and to be healthy, several things are necessary, I think that eating well, practicing some sport too, not being totally sedentary, I think this helps a lot to have good health, avoiding alcoholic beverages, I think this all helps to have good health (M.5, 29 years old). Currently, I am satisfied with this way of life, I learned to enjoy this physical activity, I will continue, it is cool, I have not reached the goal yet, but I want a goal: 25.0\% that I had in my body fat, I want to reach 15.0\%, it already decreases 5.0\% in three months, and today I feel that I can master more and seek the result (M.10, 38 years old).

On the other hand, M.1 stated that even with a need for care, he did not seek to know what was involved and what treatment was indicated. The pain in the arm that I have two months ago, I'm not going back, I do not know if it's a little lack of respect with my own body (laughs) (M.1, 55 years old).

Also, the comparison with women was verified, indicating a relational gender perspective in the construction of autonomy and self-care. The expression "it does not go anyway", used by M.2, deserved attention for a possible lack of autonomy when recognizing the need for preventive care or even seeking curative assistance in the initial moments of the conditions that intervene in the health-disease process. Because, generally, women are more delicate, do not take things the same as men. To go to the doctor, it takes a lot, he will not go anyway, he only goes when it is really bad, otherwise, he will not (M.2, 58 years old). In our head, who has to provide everything for the family is the father, is the man, he has that role in society, so often, he prioritizes these other possibilities that he has and ends up leaving his health, not doing periodic tests, things like that. The woman, you see, because of the culture, she seeks more medical care, she had her first menstruation and goes to the gynecologist, it is different (M.8, 44 years old). Since puberty, women have begun to attend, so the woman is dominating the world, they are healthy, they are staying and men are going (laughs) (M.10, 38years old).

It was observed the maturation of the man with greater age and the change of the conceptions about care and health, when the birth of a child in the life, as in the case of M.10. We have matured and begun to pay more attention to our health, because, recently, my daughter was born, so you grow up and say, "I need to take care of someone" (M.10, 38 years old).

\section{Discussion}

The results of this study had a limitation of the interpretations about the service received that were not anchored in a single type of health service and in the small number of men participating, and also because of the reduced number of men who participated expressing verbally on the answers in the structured interview.

The emotional well-being, the place where they live, financial condition, work and access to health care indicate that these men perceive these needs as determinants of health and good living conditions. The needs of good living conditions are related to lifestyle and biopsychosocial dimensions are aspects that extrapolate the health-disease process from the biological point of view, which broaden the view on what is understood about health ${ }^{(13)}$.

These needs were also identified in a survey of 11 professionals in the family health team ${ }^{(2)}$. Despite to corroborating with the aforementioned study, this 
study still progresses since the results were obtained from the patients of health services, providing an opportunity to express the voice of those who directly produce health needs.

Another necessity mentioned that maintains important relationships with a socially reproduced male universe are the work. It is pointed out in the literature that work is configured as a limiting factor in the search for healthcare by men, due to overload, lack of time or working conditions, disparity between working hours and health services, fear of falling ill and losing their job ${ }^{(7)}$. Paradoxically, from the results of this study, it was understood that the man attributes great value to the work, which allows advancing in the discussion in the health of the man to devise strategies that allow reconciling the work with the maintenance of practices and use of health services.

The speeches reinforce the view that health needs are not limited to illness but they cover aspects of cultural and social life, which are indispensable. Thus, the concept of integrality is highlighted, in the sense of inter-sectorial articulation of a set of policies, which implies a better interpretation of health needs and changes in living conditions. According to this conception, a study was carried out with 10 nurses in the Northeast of Brazil, who pointed out that the elaboration of the human health policy has not guaranteed effective assistance, that is, it has not offered integrality in care, conceived as care that meets the needs in their different natures ${ }^{(14)}$.

Regarding to guaranteeing access to health technologies, three types of technologies were identified: hard (machines, equipment, procedures), light-hard (technical) and light (relational, bonding) technologies. It must be considered that the use of hard technologies is not an indispensable guarantee for health care since the technologies do not refer only to medicines, equipment and/or procedures. Criticisms about aspects related to the form of care seem to indicate non-satisfaction with services. It is noteworthy that in these light technologies there is an intentiona- lity linked to the subjectivity of the professionals that individualizes the attendances ${ }^{(11)}$.

The findings of this study contribute to an advance in the discussion of care for men, since they direct the attention to the microenvironment of health care and show that aspects such as respect are sometimes not considered in the professional-man relationship. With this, it is possible to extrapolate the idea that men have only a short-term attitude and seek fast appointments, medications, and exams since it is observed that they also look at subjective aspects of the interpersonal relationship established with the professional that attends to it.

According to a study carried out in southeastern Brazil, along with men in chronic conditions, it is necessary to improve the communication processes with the male population to mitigate difficulties linked to superficial attention and professional requirements for men ${ }^{(15)}$. It is considered that the need for respect implies instituting a care mode centered on the individual's voice and autonomy, implementing listening, apprehension, and satisfaction of needs.

In this way, their option focuses on services that respond more quickly to clinical problems, based on medical practice and the use of medications. When they do not, they adopt measures such as self-medication that although it may seem naturalized as a daily practice, it can constitute a mark of man's role in health, permeated also by a hegemonic masculinity - independence, invulnerability and coping according to a study carried out with polymedicated elderly men ${ }^{(16)}$. This cultural model can also reinforce the relegation of prevention and health promotion to the background.

Besides the great distinction observed in daily life, health care practices and the text of policies that do not always contemplate the complexity of certain social groups, there were operational problems in this study, such as the shortage of specialist professionals, delay in marking consultations and conducting examinations/procedures. According to a study carried out 
with 255 people in a southern Brazilian state, good living conditions were among the main needs stated by the participants ${ }^{(14)}$.

When the man accesses health professionals, he is faced with the possibility of having a reference professional. This therapeutic link allows the longitudinal of care that is characterized by repeated contact with the same professional ${ }^{(17)}$. In the case of the nurse, the continuity of follow-up and the creation of lasting bonds can favor the identification and performance of male health needs. A study carried out with 27 men, aged 20 to 59 years old, who adopted the health needs taxonomy to analyze the results obtained in a semantic way, points out the reception and the bond as potential for recognition of male health needs that may qualify both the man's way of dealing with his own needs and the work of health professionals, especially the nurses ${ }^{(8)}$.

This study categorized the results, which allowed understanding different nuances of male needs, according to the dimensions explored by the referential. Thus, the model of health practices based on biologism or gender stereotypes does not facilitate the interaction of men with health services, much less the emergence of certain male needs. The lack of care impairs the reception and this obstacle can hinder the creation of the bond, the professional reference, and the co-responsibility.

When considering the Taxonomy of Health Needs, the professional work should provide the patient with a better understanding of the functioning of his organism, his illness or condition, his social relationships, increasing his possibilities of choice on the ways of conducting life. It is emphasized that the search for the needs can be an interface with the practice of the professional. Men sometimes present an attitude of carelessness with health, a way of conducting life that makes them vulnerable, but the health professional can intervene to bring man closer to better practices of self-care ${ }^{(11)}$.

The woman plays an important role in the cons- truction of the "man who cares". When they take an analytical look at themselves, they perceive the role of the women, because they consider the differences and similarities between men and women, which influence the construction of a gender identity that directs the perception and management of health needs. It is the relational perspective of gender, in which the understanding of how man is necessarily passes through the analysis of what the woman is and vice versa. Thus, from an interaction between the perceptions of both genders, the perceptions about the health of the men and, consequently, the way in which they express their own needs are verified ${ }^{(18)}$.

Thus, the results of this study corroborate with the literature and, at the same time, broaden the discussion about the health needs of men, from a socio-cultural perspective, and not only biological and epidemiological. Also, the notes on the care provided by the interviewed men contribute to reflection on the change from a service culture that is based on stereotypes to a focused and effective care.

The reports were also traced by mentions of biologically determined female characteristics that bring them closer to care and health needs. These characteristics also reflect in the organization of the health services and in the elaboration of policies and strategies of approach with the population, since they are historically based on the valuation of the care to the woman. Thus, the experience of the man who became a father, in which fatherhood brought him closer to health care, stands out. With man's health policy, practices to encourage participatory parenting were implemented and resulted in more man-caring with himself ${ }^{(19)}$.

\section{Conclusion}

Male health needs are diverse, heterogeneous and socially constructed and require inter-sectorial actions in understanding their breadth to establish effective care. 


\section{Collaborations}

Arruda GO, Corrêa ACP and Marcon SS contributed to the project design, data analysis and interpretation, article writing, critical review of the intellectual content and final approval of the version to be published.

\section{References}

1. Vasconcellos LCF, Aguiar L. Saúde do trabalhador: necessidades desconsideradas pela gestão do Sistema Único de Saúde. Saúde Debate. 2017; 41(113):605-17. doi: http://dx.doi. org/10.1590/0103-1104201711320

2. Souza MC, Araújo TM, Andrade FA, França AJ, Souza JN. Necessidades de saúde e produção do cuidado em uma unidade de saúde em um município do nordeste, Brasil. Mundo Saúde. 2014; 32(2):13948. doi: http://dx.doi.org/10.15343/01047809.20143802139148

3. Magalhães AHR, Parente JRF, Silva MAM, Pereira IH, Vasconcelos MIO, Guimarães RX. Health needs of street market saleswoman: access, connection and welcoming as integral practices. Rev Gaúcha Enferm. 2016; 37(esp):e2016-26. doi: http:// dx.doi.org/10.1590/1983-1447.2016.esp.20160026

4. Chambers SK, Hyde MK, Laurie K, Legg M, Frydenberg, Davis ID, Lowe A, Dunn J. Experiences of Australian men diagnosed with advanced prostate cancer: a qualitative study. BMJ Open. 2018; 8:e019917. doi: http://dx.doi. org/10.1136/bmjopen-2017-019917

5. Tsujimura A, Hiramatsu I, Aoki Y, Shimoyama H, Mizuno T, Nozaki T, et al. Atherosclerosis is associated with erectile function and lower urinary tract symptoms, especially nocturia, in middle-aged men. Prostate Int. 2017; 5(2):65-9. doi: https://doi.org/10.1016/j. prnil.2017.01.006

6. Separavich MA, Canesqui AM. Men's health and masculinities in the Brazilian comprehensive healthcare policy for men: a bibliographical review. Saúde Soc. 2013; 22(2):108-20. doi: http://dx.doi. org/10.1590/S0104-12902013000200013
7. Carneiro LMR, Santos MPA, Macena RHM, Vasconcelos TB. Atenção integral à saúde do homem: um desafio na atenção básica. Rev Bras Promoç Saúde [Internet]. 2016 [citado 2018 abr 05]; 29(4):554-63. Disponível em: http:// periodicos.unifor.br/RBPS/article/view/5301/ pdf

8. Storino LP, Souza KV, Silva KL. Men's health needs in primary care: user embracement and forming links with users as strengtheners of comprehensive health care. Esc Anna Nery. 2013; 17(4):638-45. doi: http:// dx.doi.org/10.5935/1414-8145.20130006

9. Cavalcanti JRD, Ferreira JA, Henriques AHB, Morais GSN, Trigueiro JVS, Torquato IMB. Integral assistance to men's health: needs, barriers and coping strategies. Esc Anna Nery. 2014; 18(4):628-34. doi: http://dx.doi. org/10.5935/1414-8145.20140089

10. Bardin L. Análise de conteúdo. São Paulo: Edições 70; 2011.

11. Silva LA, Corrêa ACP, Fraga JCAXO, Rodrigues TC, Divino EA. Men's workers perceptions about their health needs in a university health service. Ciênc Cuid Saúde. 2016; 15(1):133-40. doi: http://dx.doi.org/10.4025/ cienccuidsaude.v15i1.29321

12. Hungler BP,BeckCT, Polit DF. Fundamentos depesquisa em enfermagem - avaliação de evidência para a prática da enfermagem. Porto Alegre: Artmed; 2011.

13. Teo CRPA, Taglietti RL, Busato MA, Signor B. Autopercepção e necessidades de saúde: recurso para enfrentar vulnerabilidades e reorganizar a atenção. Espaço Saúde [Internet]. 2016 [citado 2018 fev 27];17(2):17888. Disponível em: http://www.uel.br/revistas/uel/ index.php/espacoparasaude/article/view/27091/ pdf18

14. Santos EM, Figueiredo GA,MafraALS, Reis HFT,Louzado JA, Santos GM. Saúde dos homens nas percepções de enfermeiros da Estratégia Saúde da Família. Rev APS [Internet]. 2017 [citado $2018 \mathrm{fev}$ 28];20(2):231-38. Disponível em: https://aps.uff.emnuvens.com.br/ aps/article/view/3090/1084

15. Yoshida VC, Andrade MGG. Cuidado à saúde na perspectiva de trabalhadores homens portadores de doenças crônicas. Interf Comunic Saúde Educ. 2016; 20(58):597-610. doi: http://dx.doi. org/10.1590/1807-57622015.0611 
16. Arruda GO, Lima SCS, Renovato RD. The use of medications by elderly men with polypharmacy: representations and practices. Rev Latino-Am Enfermagem. 2013; 21(6):1337-44. doi: http://dx.doi. org/10.1590/0104-1169.3004.2372

17. Soranz D, Pinto LF, Camacho LAB. Analysis of the attributes of primary health care using the electronic medical records in the city of Rio de Janeiro. Ciênc Saúde Coletiva. 2017; 22(3):819-30. doi: http://dx.doi. org/10.1590/1413-81232017223.33142016
18. Moura EC, Gomes R, Pereira GMC. Perceptions about men's health in a gender relational perspective, Brazil, 2014. Ciênc Saúde Coletiva. 2017; 22(1):291-300. doi: http://dx.doi.org/10.1590/141381232017221.17482015

19. Ribeiro CR, Gomes R, Moreira MCN. Encontros e desencontros entre a saúde do homem, a promoção da paternidade participativa e a saúde sexual e reprodutiva na atenção básica. Physis Rev Saúde Coletiva. 2017; 27(1):41-60. doi: http://dx.doi.org/10.1590/s010373312017000100003 